\title{
Slægten Ahlefeldt og Søgård
}

\section{af Mikael Venge}

I middelalderen var Ahlefeldt'erne en vigtig del af det magtfulde holstenske ridderskab, der $\mathrm{i}$ flere perioder opnåede en betydelig indflydelse i Danmark. Mikael Venge diskuterer slægtens oprindelse og baggrunden for dens erhvervelse af Søgård, der i århundreder skulle blive slægtens omstridte stamgods.

\section{De ældste Ahlefeldt'er}

Slægten Ahlefeldt tilhørte i det 14. århundrede forreste række af det holstenske aristokrati. Flere af slægtens medlemmer var riddere og fremtrædende rådgivere både for de holstenske grever og for den danske konge, Valdemar Atterdag. Dens oprindelse er imidlertid i følge sagens natur dunkel.

I det 16. århundrede, da Rantzauerne ved fantasifuld bistand af kurfyrsten af Sachsens historiograf havde fået opstillet et imponerende stamtræ, ville Ahlefeldt'erne heller ikke stå tilbage. Slægten Rantzau skulle angiveligt nedstamme fra borggreve Wiprecht af Lausitz, hvis søn omkring 1100 udvandrede til Holsten - en ren skrøne, der har været troet helt op til vore dage. Efter samme princip opfandt en vidtløftig, gejstlig kronikør, Johann Letzner (1531-1613), en ahlefeldtsk descendens fra en ridder Hunold, høvedsmand på borgen Alfeld i Sachsen og af kongeligt blod, hvis efterkommer grev Conrad i 1152 skulle være flygtet til Danmark, hvor han blev stamfader til hele den blomstrende ahlefeldtske æt.

Endnu i Olaus Heinrich Mollers imponerende arbejde, "Historische, genealogische und diplomatische Nachricht von dem uralten, adelichen Geschlecht derer von Ahlefeldt « (Flensborg 1771) figurerer grev Conrad som stamfader. Moller er dog så nøgtern, at han er klar over, at navnet hidrører fra landsbyen Ahlefeld mellem Rendsborg og Eckernförde, men han forklarer det ved, at stamfaderen havde overdraget den ene søn alle marker (»alle Felde«).

Først i Louis Bobés store værk, "Slægten Ahlefeldts Historie« I-VI (1897-1912), bliver disse skrøner eftertrykkeligt dementeret. Selv den sprænglærde og højt fortjente Bobé er dog ikke helt fri for at ligge under for myterne om slægtens oprindelse. Ahlefeldt-navnet forklarede 
han som udtrykket Anfall (et hjemfaldet len), et indfald, der vist bedst kan beskrives som en gisning, og under personlige studier i markerne omkring Ahlefeld mente han på en bakketop at finde spor af en gammel borg.

Med sikkerhed er det imidlertid næppe muligt at føre slægtens aner længere tilbage end til de to Benedikt'er i det 14. århundrede, fader og søn, som alle nulevende Ahlefeldt'er nedstammer fra. Sammenhængen med flere ældre holstenske væbnere med fornavnet Benedikt og med Bertoldus de Alefelt, der nævnes i et brev udstedt af kejser Frederik II i Syditalien 1221, er ganske uvis. Første gang slægtsnavnet optræder på nordisk grund er 1280-81, da brødrene Johann og Gerhard de Alevelde (undertiden Anevelde) stod i hertug Bugislav IV af Pommerns tjeneste, men heller ikke deres forbindelse med de holstenske Ahlefeldt'er lader sig etablere med nogen sikkerhed.

På fast grund er vi først den 26. november 1319, da ridderen Benedikt (I) de Alvelde (ca. 1280-1342) skrev kontrakt med hertug Henrik II af Mecklenburg om at forrette krigstjeneste for ham. Højst tænkeligt er han endda identisk med den væbner Benedikt, der nævnes allerede $1309 \mathrm{i}$ et pommersk dokument sammen med hr. Markvard af Rastorf. Af dokumenter fra de følgende år fremgår, at hr. Benedikt var holstener og knyttet til grev Johann den Milde, hvis lensmand han var, men hvor han har tjent sine sporer, kan vi ikke vide. Vi kan blot formode, at han efter det holstenske ridderskabs skik har skrevet sig til en lokalitet, landsbyen Ahlefeld, hvor enten han selv eller hans forfædre har ejet gods. Det var almindeligt, at de holstenske adelsfamilier tog navn efter deres hjemsted, hvad slægterne Rantzau, Sehested, Lembek og Schinkel er andre eksempler på.

Det særegne ved Ahlefeldt-navnet er, at landsbyen Ahlefeld ligger et godt stykke inde i det daværende Sønderjylland, hele $10 \mathrm{~km}$ fra Ejdergrænsen. Under stridighederne mellem Valdemarerne og de holstenske grever havde en række oprørske holstenske stormænd søgt tilflugt i Sønderjylland, »lokket ved løfter om len og pengegaver«, hedder det $\mathrm{i}$ Arnold af Lübecks krønike. Da Valdemar Sejr kort efter erobrede Holsten og Lauenburg, åbnedes vejen for en omfattende indvandring af sachsiske nybyggere i den tidligere skovgroede ødemark mellem Ejderen og Slien. Sachserne fandt dørene åbne og "tog bo i denne rigets brede forstue«, skriver Vilhelm la Cour i "Sønderjyllands Historie«. Sachserne fik dog ikke jorden til ejendom, men blev kongelige fæstere. Da kong Valdemars jordebog blev til i 1230'erne, ejede kongen 420 »hove« (bosættelser anlagt af tyske kolonister) i dette område. Vi må 
formode, at bosættelsen Ahlefeld ligesom de nærliggende landsbyer Hummelfeld og Goosfeld er anlagt i denne periode, men de nærmere omstændigheder, herunder slægtens tilknytning til stedet, lader sig næppe opklare.

Erindringen herom har sikkert heller ikke været lang. Mens det latinske »de" og det nedertyske "van « utvivlsomt oprindeligt betegnede en ægte tilknytning - af eller fra Ahlefeld - bliver prædikatet snart en ren form, der alene har betydning ved at gøre opmærksom på adelskabet og efterhånden jævnligt udelukkes. Et karakteristisk eksempel er grev Johanns privilegium for Krempe 1333, hvori de to Benedikt'er, den ældre og den yngre, betegnes »dicti de Alevelde« - som kaldes af Ahlefeldt. Her tænkes tydeligvis ikke på landsbyen eller godset Ahlefeld, som familien oprindeligt må have kaldt sig efter. I senmiddelalderen skrives navnet på nedertysk oftest Anevelde og må i datidens ører have lydt som »Udenmark « eller »Markløs«. Et forgældet medlem af slægten fik uvægerligt øgenavnet »Anegeld « - pengeløs. I løbet af det 16. århundrede sejrer 1-formen, men stadig uden $\mathrm{h}$, og først under enevælden vinder Ahlefeldt hæud som den korrekte form.

Hvad oprindelsen angår, kunne våbenskjoldet tænkes at give et fingerpeg. Det ahlefeldtske våben, der kan føres tilbage til Benedikt II's segl 1354, består af et tvedelt skjold med en ørnevinge i højre felt og to bjælker i venstre. Benedikt I's segl 1319, der nu er hensmuldret, skal have rummet de samme ingredienser. Hjelmtegnet, der træffes

Som en af Valdemar Atterdags fremtradende rådgivere beseglede Benedikt Ahlefeldt (II) landefreden $i$ Kalundborg 1360. Hans son Benedikt Ahlefeldt (III) brod imidlertid med kongen, og det var som de holstenske grevers tilhangere, at slagten satte sig fast $i$ Sonderjylland. En bred skildring af den holstenske adels fremtrangen er $i$ ovrigt givet af $H . V$. Gregersen $i$ varket Plattysk $i$ Sonderjylland (Odense 1974). Det ahlefeldtske våben på seglet fra 1360 er gengivet efter $H$. Petersen: Danske adelige Sigiller fra det XIII og XIV Aarhundrede, 1897 nr. 408

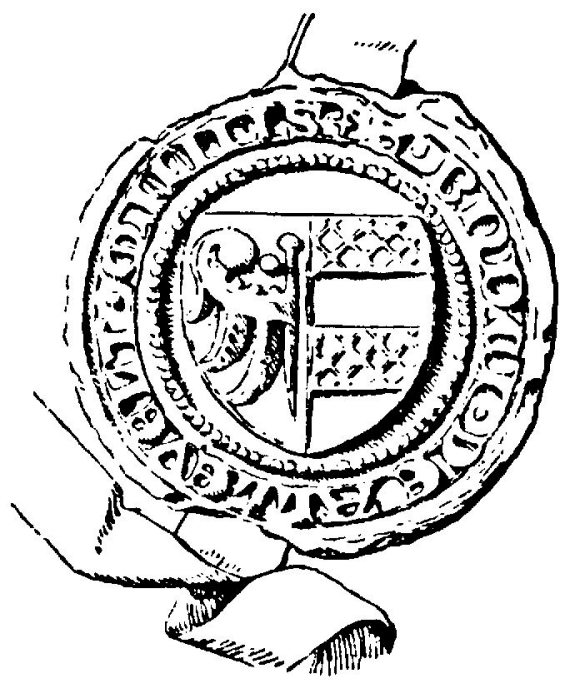


første gang 1389, er en lænket hund (senere rakke eller støver). Dette sammensatte våben kunne afspejle et slægtskabs- eller tjenesteforhold til en stormand, der har ført et vingepar som våben, men atter er vi ude på gyngende grund. Et tilsvarende våben føres af flere gamle holstenske slægter, bl.a. Rumohr - et memento om, at våben- og navneformer endnu har været flydende.

\section{Ahlefeldt'erne og Danmark}

Utvivlsomt har Benedikt Ahlefeldt været et virksomt medlem af den krigeriske og rovlystne holstenske adel, der skabte sig en position ved at deltage i de mange fejder mellem nordtyske småfyrster i 1300-tallets begyndelse. Hans stilling må allerede have været ret fremtrædende, da han i 1323 nævnes som den 6 . af 88 i det store holstenske adelsforbund.

En første tilknytning til Danmark opstod 1325, da han en kort tid under det danske riges voksende opløsning sluttede sig til kong Christoffer imod de holstenske grever. Forbindelsen peger frem mod sønnen, Benedikt II's, nære forhold til Valdemar Atterdag, men hører i øvrigt blot til en af talrige og ofte uigennemskuelige konstellationer, hvori hr. Benedikt og senere sønnen indgik.

En bemærkning i grev Gerhards privilegium for Rendsborg 1339 har givet anledning til vidtgående slutninger. Her siges det, at byens territorium gik fra Ejderen windtil den sidste grænsepæl, kaldet Pal, der står tæt ved hr. Benedikts vold«. Hvilket anlæg, der sigtes til, er imidlertid ganske usikkert. Endnu i Valdemar Atterdags erobringstogter på Sjælland i 1340'ernes begyndelse synes fader og søn at have deltaget med liv og sjæl, men herefter forsvinder den ældste hr. Benedikt af akterne. Formodentlig er han død kort efter.

Mens den ældste hr. Benedikt lagde grunden, udbyggede og fæstnede hans eneste kendte søn, Benedikt II (ca. 1310-1360), der ligesom han selv og senere sønnesønnen var ridder, slægten Ahlefeldts position. Han tilhørte inderkredsen af stormænd omkring Valdemar Atterdag samtidig med, at han havde interesser at pleje i Mecklenburg, som han formentlig har overtaget efter faderen. Tilsyneladende på egen hånd hærgede han i 1355 på Langeland, hvor han kuriøst nok belejrede slægtens senere hovedsæde, Tranekær, som på dette tidspunkt tilhørte hertug Valdemar af Sønderjylland. Da hertugen gik til modangreb, kom hr. Benedikt i stor fare, beretter Sjællandske Krønike, men heldigvis nåede Valdemar Atterdag i tide frem med undsætning. 
Samtidig med sin politiske og militære virksomhed og utvivlsomt godt hjulpet heraf var hr. Benedikt blevet en hovedrig mand. Udover de ejendomme i Holsten, som faderen må antages at have efterladt ham, havde han store besiddelser på Lolland, hvor han skrev sig til det nu forsvundne Grimstrup slot, Maribo klosters forgænger, hvis vældige borgbanke endnu ses i skoven ved Nørre sø. Desuden havde han fået Ålholm slot i pant af kongen.

Slægten Ahlefeldts første danske periode blev imidlertid af kort varighed. Hr. Benedikts ældste søn og nærmeste efterfølger, Benedikt III (ca. 1330-1405), sluttede sig i 1368 til stormandsoprøret mod Valdemar Atterdag og støttede senere mecklenburgerne mod dronning Margrethe. Herefter synes han at have trukket sig tilbage til Holsten og sammen med sin broder og deres sønner at have afviklet familiens danske besiddelser. Dronning Margrethe førte en hensynsløs reduktionspolitik over for stormændene, og det har næppe været helt frivilligt, at hr. Benedikt overlod hende både Grimstrup og Hagenskov slot på Fyn. Endvidere måtte han finde sig $\mathrm{i}$, at hun indløste hans pantelen Næsbyhoved. Faderens pantelen, Ålholm, var allerede blevet afstået i 1359. På samme måde afstod den yngre broder Johann sine godser, Kjærstrup på Tåsinge og Hørsholm i Nordsjælland, til den myndige dronning.

\section{Søgård og Tørning}

Omkring 1400 ophørte tilknytningen til selve Danmark, der først for alvor blev genoptaget 300 år senere. Hr. Benedikt (III), hans broder og deres talrige efterkommere fandt deres virkefelt i Holsten og i hertugdømmet Sønderjylland, som nu blev den holstenske adels domæne. Intet illustrerer bedre dette skifte end erhvervelsen af Søgård, der i århundreder skulle blive slægtens sønderjyske stamgods.

Hvorledes erhvervelsen kom i stand, er ganske vist en af de mange gåder $\mathrm{i}$ de ældste Ahlefeldt'ers historie, som næppe nogensinde bliver fuldt opklaret. Noget af forklaringen ligger dog utvivlsomt i de politiske forhold. Både Benedikt III's talrige sønner og efterkommerne af hans yngre broder Johann, også kaldet Henneke (ca. 1330-1390), viste sig overordentlig virksomme. Under de urolige forhold, da de holstenske grever kæmpede med det danske kongehus om herredømmet over Sønderjylland, spillede de en afgørende rolle og erhvervede efterhånden vældige besiddelser, der gennem århundreder kom til at følge de forskellige linier, som slægten snart forgrenede sig $i$. 
Hvor hr. Benedikt residerede efter, at han havde afviklet sine danske godser, vides ikke, men måske står erhvervelsen af Søgård i forbindelse hermed. I 1389 havde dronning Margrethe indløst Næsbyhoved slot for 9.000 mark. Hvis denne uhyre sum virkelig er blevet betalt, må han være kommet i besiddelse af en betydelig kapital. I 1398 fulgte den endelige afregning for afhændelsen af Grimstrup og Hagenskov, der atter på papiret gav anledning til en betydelig udbetaling. Kvitteringen blev beseglet af den gamle hr. Benedikt selv og fem af hans sønner, hvoraf de tre allerede var riddere - et vidnesbyrd om familiens aktive deltagelse i kampene om Sønderjylland.

Hvor er disse efter tidens forhold kolossale beløb havnet? Påfaldende er det unægteligt, at den ældste søn, Claus Ahlefeldt, samme år af hertug Gerhard fik Lundtoft herred i pant. Lundtoft herred omsluttede Søgård, som slægten altså på dette tidspunkt har været i besiddelse af. Søgård lå på et næs i den store sø, gården har navn efter, som nu er gennemskåret af landevejen mellem Aabenraa og Flensborg. Det var en gammel kongsgård, som via Abelætten var overgået til den mægtige Limbækslægt, vel i forste omgang som et len ligesom herredet, hvis administrative centrum den var, men under hertugernes svækkelse kom godset snart i Limbækkernes private besiddelse. Endnu i 1370'erne ejedes Søgård af Lyder Limbæk, en fætter til den mægtige drost, Claus Limbæk.

Kort efter er det, at vi finder den i Ahlefeldt'ernes besiddelse. Det ser underligt ud. Louis Bobé har ganske vist opstillet en teori om flere ægteskabsforbindelser, der kunne forklare transaktionen, og helt grebet ud af luften er denne tanke ikke. Mens de to første Benedikt'ers hustruer er ukendte, kender vi navnet på Benedikt III's ægtefælle fra en af de ansøgninger om pavelig syndsforladelse, som datidens europæiske overklasse yndede at indgive. Hun hed Catherine, og det samme hed en af drosten Claus Limbæks døtre. Hr. Claus Ahlefeldt kunne da være opkaldt efter sin mægtige morfader. Problemet er blot, at Lyder Limbæk, drostens fætter og Søgårds ejer, havde tre sønner og hele syv brødre, som man skulle tro var nærmere til at overtage godset, selv hvis vi antager, at Claus Ahlefeldts hustru, som er ganske ukendt, også var arveberettiget. Problemet løses altså ikke uden videre. Det sandsynligste er vel, at Søgård er kommet i Ahlefeldt'ernes besiddelse som et led $\mathrm{i}$ et kompliceret sæt opgørelser mellem det danske kongehus, Limbækkerne og de holstenske grever, hvis trofaste støtte slægten var blevet.

På samme måde er formodentlig Tørning slots overgang til hr. Claus' 
fætter, Henrik Ahlefeldt (ca. 1370-1430), foregået. Tørning, der nu henligger som en skovklædt ruin på en stejl banke vest for Haderslev, var ligesom Søgård oprindeligt krongods, der kom i Limbækkernes besiddelse kombineret med et stort pantelen. Også Henrik Ahlefeldt var ridder og har altså været en ivrig deltager i kampene mod Erik af Pommern, som de holstenske grever i disse år førte med stor kraft.

Andre Ahlefeldt'er erhvervede sig godser i landskabet Dänischwohld, den gamle grænseskov Jarnwith mellem Kieler fjord og Eckernförde bugt, som nu af den indtrængende holstenske adel blev kaldt »den danske skov«. Den centrale landsby i Dänischwohld og det eneste stednavn af tydeligt dansk oprindelse, Gettorf, blev tidligt en ahlefeldsk besiddelse. Mod nord ejede en anden af Benedikt III's mange sønner, Wulf Ahlefeldt (ca. 1360-1430), godserne Nør og Grönwohld, som han formodentlig har arvet efter faderen. En gammel, næsten udvisket gravsten foran alteret $\mathrm{i}$ Gettorf kirke menes at dække over ham og hans hustru. Nør og Grönwohld forblev i Wulf Ahlefeldts yngste søn Schacks efterkommeres besiddelse ind i det 17. århundrede. Den aldste søn, Benedikt, fik godset Borghorst, og hans efterkommere blev Ahlefeldt'erne på Gelting.

Den sydlige del af Dänischwohld, samlet omkring det skovrige Lindau med dets store tilliggender, erhvervedes senere under Christian I af hr. Claus til Søgårds yngste søn, Godske, den første Ahlefeldt af dette navn (ofte kaldet Gotskalk eller Gossick). Godske Ahlefeldt (ca. 1400-1475) skrev sig egentlig til borgen Bossee ved Westensee, som splittedes under hans efterkommere, hvorved godser som Schierensee, Emkendorf og Deutsch Nienhof opstod. Af Lindau, der forblev på slægtens hænder indtil vor tid, opstod godserne Königsförde og Wulfshagen. Også hr. Claus' næstyngste søn, Johann, var en hovedrig mand. Han ejede godserne Lehmkulen og Wittmoldt mellem Preetz og Plön og skænkede i 1460 den pragtfulde altertavle i St. Nicolai kirke i Kiel. Denne altertavle stammer egentlig fra Vor Frue kloster af franciskanerordenen, som Johann Ahlefeldt ligesom sine slægtninge og i øvrigt også kongehuset patroniserede, men blev i 1541 overført til St. Nicolai.

\section{Slægtsfølelse}

På kun 100 år var hr. Benedikt II's sønner og deres børn blevet til den ahlefeldtske slægt, hvis talrige medlemmer sad på store godser i Holsten og Sønderjylland og indtog fremtrædende poster i grevernes og senere hertugernes tjeneste. Næppe nogen anden slægt i 1400-tallet kom for- 
mentlig i rigdom og indflydelse på højde med Ahlefeldt'erne. De to hovedlinier, efterkommerne af Benedikt II's sønner Benedikt III og Johann, havde hver sit stærkt befæstede slot, omgivet af et omfattende godskompleks, hvor overhovedet levede en næsten fyrstelig tilværelse.

Naturligvis krævede denne position ofre. Slægtens mandefald i de tre Ditmarskerkrige 1404, 1500 og 1559 var betydelige. I 1404, da "Holstens ædelsten og lys gik under med de herlige mænd«, som det hedder i Holstenerpræstens krønike, skal flere hundrede medlemmer af ridderskabet være faldet. Blandt dem var Benedikt III's to ældste sønner, Claus og Henrik, der spillede en vigtig rolle under felttoget Claus som anfører for rytteriet og Henrik for bueskytterne - en rolle, som krøniken yderligere udpensler. På samme måde dvæler Detmars krønike ved fætteren Henrik Ahlefeldts rolle under Flensborgs belejring 1427. Ingen af disse skildringer er autentiske, men de vidner i det mindste om slægtens anseelse i samtiden.

En voksende slægtsfølelse antydes ligeledes af flere vidnesbyrd. I 1456 blev der oprettet en familiestiftelse ved Marianerkapellet i Haderslev domkirke. Det økonomiske fundament bestod af fæstegods fra Tørning og Søgård, slægtens to hovedsæder, idet Ahlefeldt'erne på Tørning tilsyneladende bar den største byrde. Et gammelt notat $\mathbf{i}$ familiearkivet på Olpenitz om, at stiftelsen blev oprettet af et beløb på 2.000 mark, som var givet i sone for drabet på en af Benedikt III's sønner på Gram kirkegård,' altså 50 år tidligere, må anses for en skrøne. Beløbet er ganske vist korrekt, men fremkom ved, at der af Tørning blev afgivet gods i Hammelev og Vedsted for 1700 mark og af Søgård gods i Kliplev for 300 mark. Da en lang række af slægtens medlemmer nævnes som stiftere, har man antagelig arrangeret sig indbyrdes om betalingen, men i betragtning af Tørnings nære beliggenhed og særlige forhold til Marianerkapellet er det vel naturligt, at familien her har skæppet mest. Dette forhold er i øvrigt det bedste bevis for, at historien om drabet på Gram kirkegård ikke kan passe, idet Ahlefeldt'erne på Tørning ikke nedstammede fra Benedikt III, men fra hans yngre broder og altså ikke havde del i sonen for drabet på en af hans sønner.

Af indtægterne fra godset blev der lønnet fire præster, der hver dag året rundt skulle afholde gudstjenester til slægtens tarv. I fundatsen ${ }^{2}$ understreges det, at kapellet i sin tid var opført af fru Eibe Limbæk endnu et tegn på, at der har bestået en familiemæssig tilknytning mellem Limbækslægten og Ahlefeldt'erne, dens afløsere både på Søgård og Tørning. I 1496 kaldes kapellet det ahlefeldtske kapel. 
Gudstjenesten var særdeles omfattende. Døgnet rundt skulle jomfru Marias tider holdes. Hertil kom to daglige messer. Ved den ene, der blev sunget, mindedes alle slægtens afdøde, dog især stifterne, og ved den anden, der læstes før eller efter den sungne messe, skulle der bedes en særlig bøn til gavn for alle levende af slægten Ahlefeldt - »tho bestendicheyt unde heyle des gantzen slechtes van Anevelde«, som det hedder i Slesvig-bispen Claus Wulfs bekræftelse af fundatsen. Endelig skulle der ved højtiderne holdes særlige messer.

Den fornemme stiftelse vidner om et imponerende sammenhold mellem en række fætre og halvfætre, der alle nedstammede fra Benedikt II, de fleste også fra Benedikt III, ${ }^{3}$ og den gentagne påberåbelse af »slægten « Ahlefeldt om en betydelig slægtsstolthed. Stiftere var i første række de to endnu levende af hr. Claus til Søgårds sønner, Johann Ahlefeldt til Lehmkulen og Wittmoldt og Godske Ahlefeldt til Bossee og Lindau, samt deres halvfætter Benedikt, Tørnings ejer. Endvidere nævnes farbroderen Wulf Ahlefeldts fire sønner og af den næste generation Claus Ahlefeldt til Søgård og hans yngre broder Peter, hr. Johanns fire sønner og Godske Ahlefeldts fire sønner.

Om slægtsfølelse og adelsstolthed vidner fundatsens ærbødige omtale af stifterne som riddere og væbnere "des gantzen slechtes van Anevelde«. Slægten forbeholdt sig fortsat opsynet med, at det donerede fæstegods anvendtes efter sin bestemmelse, og dette opsyn skulle udøves af dens ældste medlemmer, idet riddere dog skulle gå forud. Man har altså forestillet sig et fortsat nært sammenhold mellem Benedikt II's efterkommere. Fra opsynet undtoges $\mathrm{i} ø v$ rigt et enkelt, åbenbart vanartet medlem af slægten, Henneke Ahlefeldt til Rieseby og hans efterkommere, der for tid og evighed blev udelukket fra indflydelse på stiftelsen. Baggrunden for den mærkværdige bestemmelse må vel være, at Henneke har modsat sig stiftelsens oprettelse. Han kan være identisk med Johann Ahlefeldt til Lehmkulens søn af dette navn, men da denne søn optræder i fundatsen og i øvrigt gjorde en ganske normal karriere, forekommer det usandsynligt. Snarere er der tale om den ukendte Henneke, der var søn af Benedikt Ahlefeldt til Søgård (ca. 1390-1440) og altså en yngre broder til Claus og Peter Ahlefeldt. Rieseby var et hertugeligt pantelen på halvøen Schwansen syd for Slien. Her kan man have fået familiens sorte făr anbragt.

Slægtens mest fremtrædende medlem på dette tidspunkt var Johann Ahlefeldt til Lehmkulen og Wittmoldt, der både var ældst og den eneste ridder. Som værge (kurator) for Preetz kloster var han tillige fornemt placeret inden for hele det holstenske ridderskab. Sikkert har 


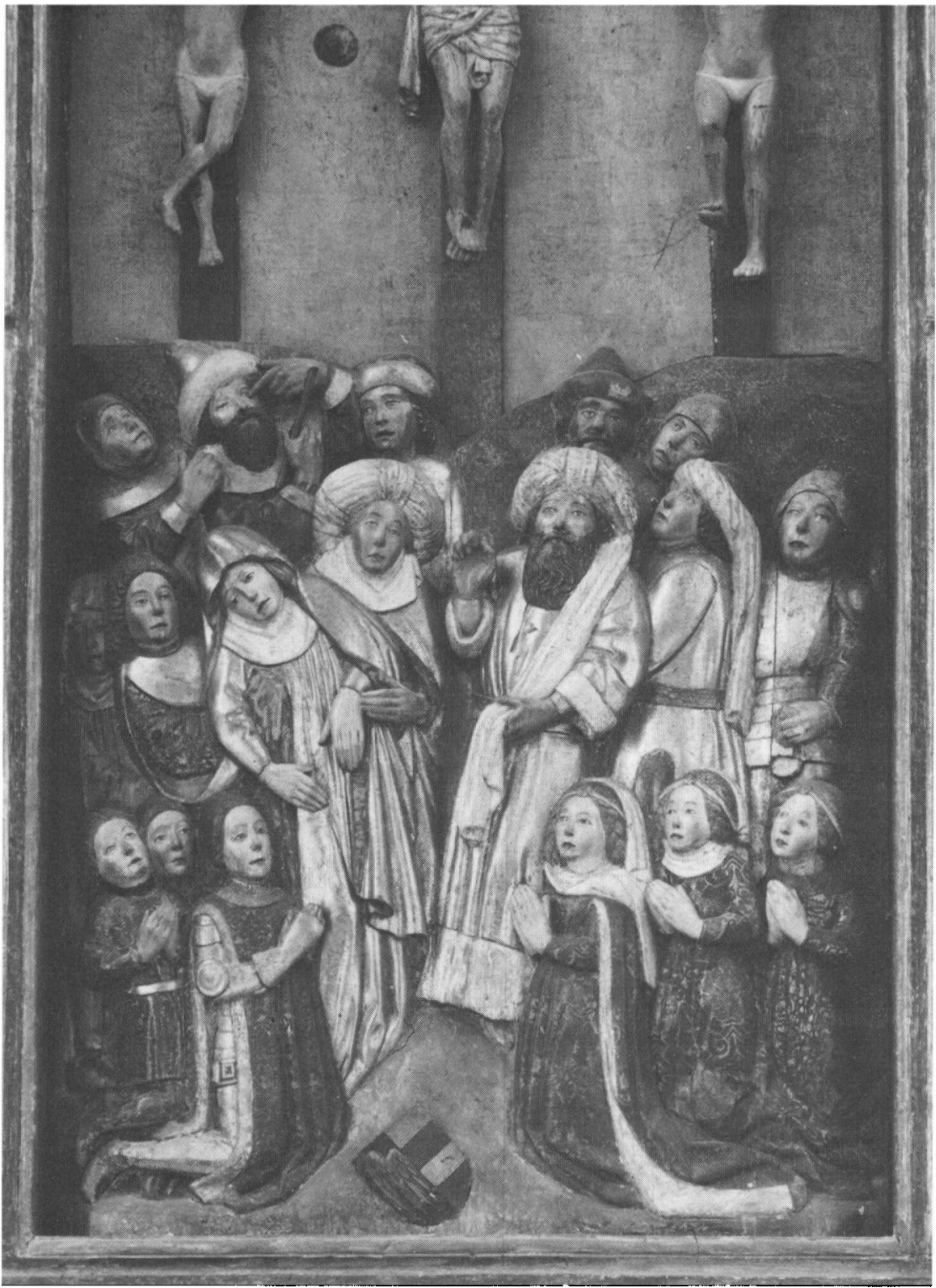

Altertavlen $i$ St. Nikolai kirke $i$ Kiel er en af de storste og $i$ kunstnerisk henseende mest vardifulde $i$ hertugdommerne. Den er skanket til franciskanerklostret $i$ Kiel $i 1460$ af Johann Ahlefeldt. På altertavlens midterbillede ses nederst $i$ midten det ahlefeldtske väben og på begge sider knaler $i$ forgrunden stifterne, formentlig Johann Ahlefeldt og hans hustru. Bag dem ses sandsynligvis hr. Johanns fader og bedstefader og deres hustruer. Foto: Landesamt für Denkmalpflege Schleswig-Holstein. 
han haft et stort ord at skulle sige ved fundatsens udformning. Allerede i 1445 havde han stiftet en lignende messeordning af mindre omfang ved Vor Frue kloster i Kiel. Her blev der bedt for hr. Johann selv og hans familie, hans forældre og bedsteforældre, et udtryk for samme slægtsfølelse som Marianerstiftelsen. På altertavlen, som Johann Ahlefeldt skænkede til klostret i 1460, er han selv og hans hustru fremstillet knælende $\mathrm{i}$ forgrunden. Bag hver af dem ses to andre skikkelser, der er blevet opfattet som ægteparrets børn. Der kan imidlertid ikke være tvivl om, at figurerne forestiller faderen og bedstefaderen og deres hustruer, ikke realistisk fremstillet naturligvis, men dog historiske portrætter af den første hr. Claus på Søgård og hans fader, Benedikt III.

\section{Haseldorf}

Den politiske udvikling havde for så vidt formet sig til Ahlefeldt'ernes gunst. De holstenske grever af det schauenburgske hus, som de havde knyttet sig til, havde sejret i Sønderjylland, og deres arvtager, Christian I, blev 1448 dansk konge og fik 1460 tillige hertugdømmet og Holsten. Under disse omskiftelser var slægtens fremtrædende medlemmer stærkt medvirkende. På længere sigt måtte de rige Ahlefeldt'er dog uundgåeligt komme under pres fra den konsoliderede fyrstemagt. Under den dybt forgaldede Christian I var der endnu frit spil, men hans sønner havde snart deres fangarme ude efter slægtens to befæstede bastioner. I 1498 indløste hertug Frederik Lundtoft herred fra Søgårds ejere, Claus Ahlefeldts sønner, efter at han til brødrenes store fortørnelse havde afkøbt deres søster hendes søsterlod.

Det blev dog slægtens anden sønderjyske bastion, der først gik tabt. Det huede tydeligt ikke fyrstemagten at have ridderskabet siddende $\mathrm{i}$ det nordlige Sønderjylland, som man på enhver måde stræbte efter at gøre til et kongeligt og hertugeligt domæne. På Tørning sad i Christian I's tid Benedikt Ahlefeldt, en af medstifterne af familiestiftelsen i Marianerkapellet og sønnesøn af hr. Johann, Benedikt II's yngre søn. Efter hans død delte hans sønner Hans og Henrik Tørning, idet Hans fik selve borgen og det meste af godset.

Hans Ahlefeldt stod kongehuset nær. Han blev tidligt ridder, gift med den danske rigshofmester Erik Ottesen Rosenkrantz' datter og befandt sig tilsyneladende foran en stor løbebane i kongeriget. Det blev imidlertid først hans efterkommere, der 150 år senere genoptog denne forbindelse. I 1494, da hans danske hustru allerede var død og 
afløst af en holstensk adelsdame, måtte Hans Ahlefeldt og hans broder overdrage Tørning til kong Hans. Det skete - sikkert i god forståelse - ved en kompliceret transaktion, hvorved Hans Ahlefeldt fik Haseldorf gods ved Elben med vældige tilliggender i den frugtbare marsk, givetvis ikke noget dårligt bytte. I tilgift fik han ovenikøbet yderligere to godser, Kaden nord for Hamburg og Gelting i Sydslesvig, mens broderen Henrik fik godset Pronstorf ved Segeberg.

Der er ingen tvivl om, at kong Hans strakte sig meget vidt for at gøre sin jævnaldrende navnefælle tilfreds. Tønder amt, som han havde haft $\mathrm{i}$ forlening, fik han ombyttet med Segeberg, der lå langt mere bekvemt for hans nye besiddelser. Men herved var slægten Ahlefeldts yngre linie, der snart skulle vise sig at være den kraftigste gren, blevet forrykket til det oldenburgske monarkis periferi.

Haseldorf, hvor hr. Hans førte en særdeles herskabelig tilværelse, blev i århundreder Ahlefeldt'ernes hjemsted, indtil godset i 1732 overgik til slægten von Schilden. Her var det, at Louis Bobé i slutningen af forrige århundrede fandt slægtens store arkiv, der efter ejerskiftet var forblevet på Haseldorf. Arkivet bestod af tre stuer fyldt med papirer »henslængte på hylder og over gulve mellem alt muligt skrammel, kasser og kufferter, gamle rustne våben, tæpper, seletøj og udrangerede, mølfyldte stadsdragter, og yderligere bragte i vildeste uorden af trækken gennem de splintrede vinduer, hvortil kom den ødelæggelse mus, fluer og møl uforstyrret havde anrettet «. ${ }^{4}$ Den altid elskværdige Bobé skynder sig at tilføje: "Trods alt måtte man ære den pietet, der havde frelst papirerne fra brutal tilintetgørelse«. Det er Louis Bobés store fortjeneste, at han bragte orden i dette kaos, og det haseldorfske arkiv blev en guldgrube for ham $\mathrm{i}$ hans arbejde med slægtens historie.

\section{Slaget ved Hemmingstedt}

Erhvervelsen af Haseldorf havde imidlertid bragt Hans Ahlefeldt farligt nær det frie Ditmarsken, hvis uafhængighed var en torn $i$ øjet på fyrstemagt og ridderskab i hertugdømmerne. Næsten 100 år var forløbet siden det sidste forsøg på at knægte de frie bønder, hvorunder hr. Hans' farfaders to fætre var faldet, da det i slutningen af 1490'erne trak op til en ny konflikt. Efter bosættelsen i Elbmarsken var det naturligt, at han med sit nære forhold til kongehuset stod bag udrustningen af den forenede kongelige og hertugelige hær, og det vidner om 
kong Hans' tillid til ham, at han, en holstensk ridder, blev betroet at føre det kongelige banner, det gamle Dannebrog.

Det stort anlagte felttog førte imidlertid til et forsmædeligt nederlag. I slaget ved Hemmingstedt den 17 . februar 1500 sprællede atter blomsten af det holstenske ridderskab i pløret, mens kong Hans og hertug Frederik dog undgik hertug Gerhards skæbne i 1404 og reddede livet. Blandt de faldne var Hans Ahlefeldt og talrige af hans slægt, heraf adskillige af høj alder. To faldne brødre, Benedikt og Ditlev Ahlefeldt, sønner af hr. Johann til Lehmkulen og medstiftere af Marianerstiftelsen 1456, må begge have været omkring 70 år, men har altså fulgt deres standsfæller i felten. Deres tre fætre, Henrik Ahlefeldt til Lindau, Henneke Ahlefeldt til Bossee og Emkendorf og Markvard Ahlefeldt til Deutsch Nienhof og Saxtorf, sønner af Goske Ahlefeldt, må have været næsten jævnaldrende. Af den yngre generation faldt en sønnesøn af hr. Johann, Henrik, der var amtmand på Steinburg, det holstenske amt, der grænsede op til Ditmarsken, samt fire sønnesønner af Wulf Ahlefeldt til Grönwohld, tre Benedikt'er, hvoraf den ene var hertug Frederiks kammermester, og en af hertugens hofsinder, Lorentz Ahlefeldt. Endelig faldt den ene af Søgårds to ejere på dette tidspunkt, Jørgen Ahlefeldt.

I samtiden må efterretningen om nederlaget have virket lammende. For Ahlefeldt'erne var det en kraftig åreladning. Hele 12 medlemmer af slægten faldt, et vidnesbyrd om dens fremtrædende placering $i$ hertugdømmerne. Mandefaldet er nok en del af forklaringen på, at Ahlefeldt'erne i det 16. århundrede blev overfløjet af Rantzauerne som den dominerende slægt $\mathbf{i}$ hertugdømmerne. Efter tabet af Hans Ahlefeldt savnedes en stor personlighed med politisk indflydelse, der kunne værne slægtens position. Slægten Ahlefeldt havde naturligvis fortsat mange fremtrædende medlemmer, men først i det 17 . århundrede hævede den sig atter markant over sine standsfæller.

\section{Gejstlige Ahlefeldt'er}

Kort før reformationen nåede slægten at levere flere fremtrædende gejstlige. For at undgå yderligere splittelse af familiegodserne var det naturligt, at selv de rige Ahlefeldt'er opdrog nogle af deres sønner med henblik på en gejstlig løbebane ligesom adskillige døtre blev indsat $\mathbf{i}$ St. Laurentius-klostret i Itzehoe. To sønner af Benedikt Ahlefeldt til Borghorst, Godske og Johann Ahlefeldt, studerede som unge ved 


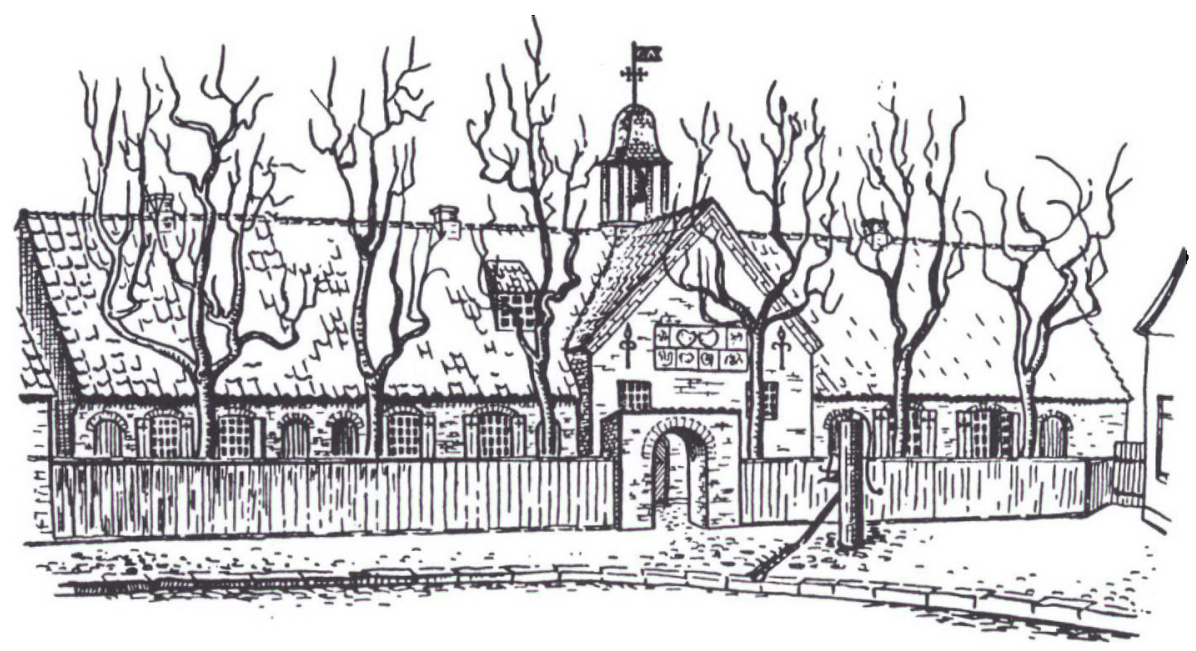

Goschhof $i$ Eckernförde blev indrettet som stiftelse for fattige af Godske Ahlefeldt $i 1534$. I 1578, og atter $i$ 1773, blev bygningen fornyet. Det var en énetages lange. I midten lå kapellet bag gavlrisalitten. I gavlen sad en indskrifttavle til minde om Godske Ahlefeldt. Bygningen blev nedrevet i 1879-80. Gengivet efter Die Kunstdenkmäler des Kreises Eckernförde, 1950 s. 138

universitetet i Rostock. Her må de have klaret sig hæderligt, thi i 1502 blev de begge indskrevet ved universitetet i Bologna, datidens Harvard og den sikre vej til embeder i kirke og stat. Her døde den unge Johann, men Godske Ahlefeldt (ca. 1470-1535) studerede videre, ganske vist uden at tage nogen højere eksamen. Fire-fem år senere vendte han hjem til hertugdømmerne, hvor han i mange år bestred nogle mindre, men øjensynligt ganske indbringende gejstlige embeder og i øvrigt førte en stille og beskeden tilværelse på sin gård ved Eckernförde, hvor han havde sit hjem nær fædrenegården Borghorst.

At en søn blev gejstlig betød ikke, at han fraskrev sig retten til fædrene arv, blot at han holdt sig tilbage og stillede sig tilfreds med kontanter og strøgods, mens selve familiegodset blev overladt til brødrene. Alt $\mathrm{i}$ alt har vi grund til at formode, at den stilfærdige hr. Godske har været en temmelig velhavende mand. Bortset fra de få ydre holdepunkter er det eneste, man ved om ham, at han kort før sin død oprettede et testamente, ${ }^{5}$ hvorved han skænkede gården ved Eckernförde til en stiftelse for fattige.

Gården lå uden for byens søndre port og har vel været af en land- 
stedsagtig karakter. Selv siger hr. Godske i sit testamente, at han boede "for « Eckernförde. Som mange af sin nærmeste slægt var han upåvirket af reformationens rørelser - forblevet en from katolik. I testamentet er han tydeligt meget optaget af indretningen af et kapel på gården, som han håbede ville blive fuldendt inden hans død, og hvor han selv onskede at blive begravet. Åbenbart havde han også tænkt sig selv at indvie dette kapel på katolsk vis. I testamentet bestemmes, at hvis han døde inden fuldførelsen, skulle hans slægtning af samme navn, biskop Godske Ahlefeldt (ca. 1470-1541), der var hans halvfætters søn, indvie det.

Ved testamentets oprettelse havde stiftelsen længe været påtænkt, og fundatsen var allerede godkendt af hr. Godskes afdøde brødre, Claus Ahlefeldt til Gelting (ca. 1470-1531) og Henrik Ahlefeldt til Satrupholm (ca. 1470-1532). Testamentet indeholder derfor ingen nærmere bestemmelser om selve stiftelsen, der skulle yde otte nødlidende familier ophold og underhold, men fastslår blot nogle økonomiske og juridiske rammer. Hele Godske Ahlefeldts formue tilfaldt stiftelsen. Der skulle ansættes en dygtig mand eller kvinde som bestyrer og to kompetente og stærke tjenestepiger til at bistå med husførelsen samt en præst, der både kunne forrette gudstjenester, yde beboerne et kristeligt tilsyn og føre regnskaber. Det lyder nærmest, som om stiftelsen var tænkt som et hospital, hvor gamle og svage kunne finde pleje. Efter tidens lidt barske normer tog man det ikke så nøje med lemmernes forsørgelse. Dagligt eller ugentligt skulle der udbetales et beløb, hvoraf de antoges at forsørge sig selv. Dog blev der også taget højde for, at bestyreren kunne brygge og bage til lemmernes behov.

Godske Ahlefeldts stiftelse levner et ejendommeligt indtryk af en særpræget personlighed i en ellers mørklagt periode. Stiftelsens idealer repræsenterer en bemærkelsesværdig overgang mellem senmiddelalderlig fromhed og den nye tids humanisme og sociale forståelse. Bemærkelsesværdigt er det også, at stiftelsen ikke blev modarbejdet af slægten, men tværtimod understøttedes på enhver måde. At Godske Ahlefeldt selv har næret følelser for sin slægt, kan næppe være tvivlsomt, selv om hele hans formue gik til stiftelsen. Af testamentet fremgår det, at gårdens bageste gemak, der velsagtens har været hans egen stue, med de to tilstødende kamre skulle stilles til rådighed for testamentets eksekutorer, stiftelsens patroner og hr. Godskes venner, hvis de ønskede at overnatte der. Med venner menes antagelig slægtninge. Eksekutorerne var hr. Godskes fætter Wulf Ahlefeldt til Nør og Grönwohld (ca. 1470-1545) og en fjernere slægtning og navnefælle, Godske Ahlefeldt 
til Saxtorf (ca. 1480-1545), søn af halvfætteren Markvard og fætter til biskoppen. Begge udmærkede sig ved at tilhøre hr. Godskes egen generation og sidde på store godser i Eckernfördes omegn. Patronerne derimod, var hr. Godskes potentielle arvinger, brodersønnerne, der som trøst fik myndighed til at indsætte nye eksekutorer, stiftelsens egentlige kuratorer, når de to første var faldet fra. Eksekutorerne skulle være blandt de ældste af "huset « Ahlefeldt og bosiddende i nærheden af Eckernförde.

Højst tænkeligt ville Godske Ahlefeldt under andre omstændigheder have skænket sin formue til familiestiftelsen i Haderslev, Marianerstiftelsen af 1456, som hans farfader, Benedikt, havde været medstifter af. Det hører med i billedet, at de kirkelige institutioner i hertugdømmerne ved Godskestiftelsens oprettelse var i fuld opløsning. Haderslev havde siden 1520'erne været residens for den kætterske hertug Christian (III), der med ildhu forfulgte alle katolske levn, og som på tidspunktet for testamentets affattelse var blevet regerende hertug og stod for at skulle være dansk konge. At hr. Godskes stiftelse fik sin særlige udformning indebar også en tilpasning til de nye tider.

Denne familiemæssige side af stiftelsen har tydeligt ligget hr. Godske meget på sinde. I sit testamente tager han det løfte af eksekutorerne, at de ville arbejde for, at Marianerstiftelsen og visse andre indkomster, slægten Ahlefeldt må have haft fordring på, blev forenet med hans egen stiftelse. Det skete virkelig. I 1541 ophævedes Marianerstiftelsen og dens rige midler overførtes til Godskestiftelsen, der således i endnu højere grad blev en familiestiftelse. I denne skikkelse eksisterer den endnu i dag, efter at selve "der Goschhof i 1879 måtte vige for en byudvidelse.

Godske Ahlefeldts jævnaldrende slægtning af samme navn, biskop Godske Ahlefeldt, indledte sin løbebane på samme måde, men nærede øjensynligt langt videre ambitioner. Allerede i 1490'erne opholdt han sig ved pave Alexander Borgias hof $\mathrm{i}$ Rom, hvor han hurtigt gjorde sig fordelagtigt galdende at dømme efter de indbringende embeder, han tildeltes. I 1498 indledte han sine studier ved Bolognas universitet, som han i 1501 kunne forlade med titel af doktor i kanonisk ret. Efter hjemkomsten var han i kraft af sin høje byrd og sin akademiske baggrund selvskreven til stillingen som hertug Frederiks kansler. I 1504 fik han tillagt domprovstiet i Slesvig, og i 1507 valgtes han til biskop. Han forblev dog fortsat nært knyttet til hertugen, og det skyldtes utvivlsomt hensynet til ham, at fyrstehuset gik yderst varsomt til værks over for den katolske gejstlighed i hertugdømmerne. Mens kollegerne 


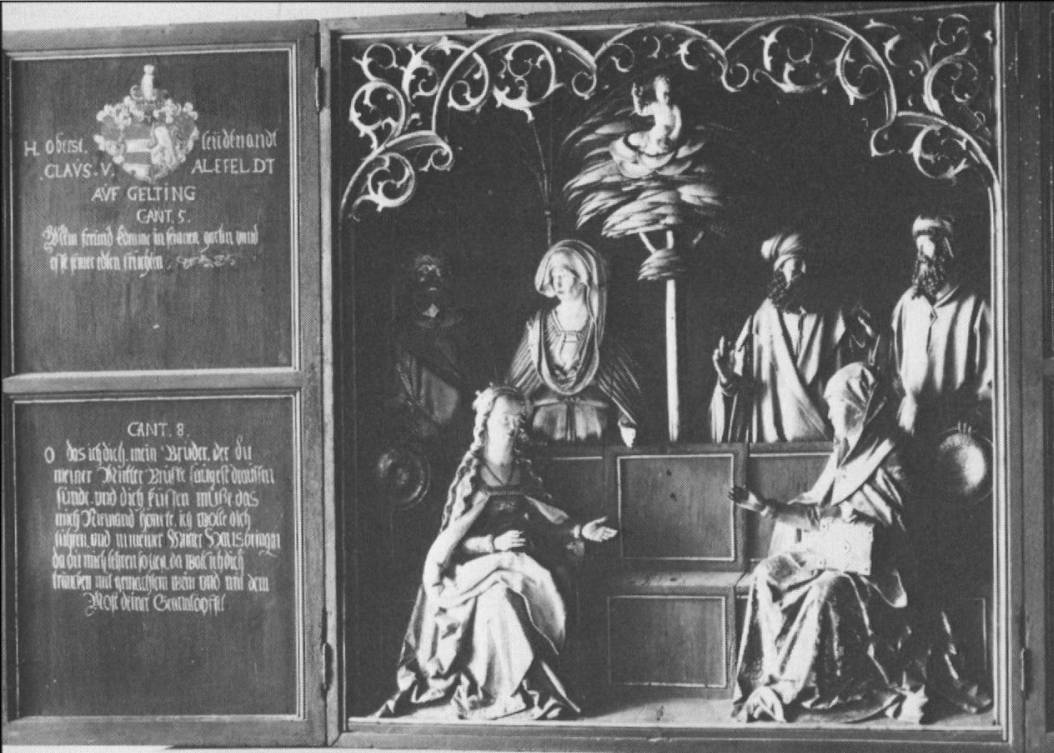


Kort efter sin tiltrædelse indgik biskop Godske en overenskomst med sin broder Ditlev (ca. 1480-1540), hvorved han overlod ham deres rørlige fædrene og mødrene arv (husgeråd og andet inventar, klædedragter og kostbarheder) for 1500 mark. Samtidig var Ditlev Ahlefeldt blevet ansat som stiftets "amtmand « eller »foged «, således at der ikke kan være tvivl om, hvor de 1500 mark blev hentet. Som amtmand kunne Ditlev Ahlefeldt residere på bispestolens befæstede slot, Schwabstedt ved Ejderen. Derimod nåede han næppe at tage ærkedegnegården i Slesvig i besiddelse, som han i 1529 fik brev på, idet indehaveren, halvfætteren Joakim Ahlefeldt fra Søgård, mod forventning levede lige så længe som han selv. Godske og Ditlev Ahlefeldts fædrenegård var det nu forsvundne Bollingstedt nord for Slesvig. De to brødre, der virkede snævert sammen i stiftet, ejede også fædrenegården i fallesskab, og det var her, biskop Godske døde.

Sine andre slægtninge stod han ligeledes nær og blev understøttet af dem i sit forsvar for katolicismen. Til gengæld optrådte han særdeles imødekommende over for dem. Claus og Henrik Ahlefeldt - navnefællen, stifteren af Goschenhofs brødre - havde uvist af hvilken grund og uden, at de nærmere omstændigheder kendes, kort efter 1500 afhændet fædrenegården Borghorst. Formodentlig har familiens økonomi været anstrengt. I 1519 kunne Claus Ahlefeldt imidlertid erhverve Gelting fra boet efter Benedikt Ahlefeldt til Haseldorf, hr. Hans' ældste søn, men den yngre broder havde stadig intet gods.

Da trådte antagelig biskop Godske til og foranledigede, at domkapitlet i 1528 solgte Satrupholm syd for Flensborg til ham. I disse år måtte gejstligheden nødtvungent holde udsalg af sine besiddelser, og blandt ridderskabet var der kappestrid om at erhverve disse store, værdifulde godser, der $\mathrm{i}$ århundreder havde ligget urørlige hen i kirkens varetægt. Her havde Ahlefeldt'erne øjensynligt forkøbsret. I 1539 solgte biskop Godske til sin fætter, der også hed Godske Ahlefeldt (Goschenhofs kurator), den gamle bispeborg Stubbe ved Slien, der på forbilledlig vis kompletterede hans eget gods Saxtorf.

\section{Ahlefeldt'erne på Søgård}

Af de tre næsten jævnaldrende gejstlige Ahlefeldt'er på reformationstiden var den allerede nævnte ærkedegn Joakim Ahlefeldt fra Søgård (ca. 1465-1540) den ældste og den, der nåede den højeste alder. Han residerede $\mathrm{i}$ sin embedsbolig, ærkedegnegården i Slesvig, men havde samtidig rådighed over østfløjen af Søgård, som han må have benyttet 
til at rekreere sig i landlige omgivelser. For en blomstrende slægt som Ahlefeldt'erne blev presset på de fædrene godser ved middelalderens slutning stærkt. Joakim Ahlefeldt er et karakteristisk eksempel på, at det hjalp, når enkelte sønner ofrede sig og valgte en gejstlig løbebane, men i Søgårds tilfælde var det ikke nok.

Det er mærkeligt at se, hvor svært man havde ved at bekvemme sig til at dele dette stamgods. Da Johann Rantzau i 1563 skrev sit testamente, bestemte han, at den ældste søn skulle arve Breitenburg, men at slottet i ufredstider skulle stå åbent for den yngre søn og hans familie. På Søgård gik man endnu videre. Vi har allerede set, at ærkedegnen beholdt rådighed over østfløjen af fædrenegården. På samme måde valgte man $i$ generation efter generation at dele selve hovedbygningen mellem flere brødre og deres familier. Åbenbart har Søgårds særlige beskyttede beliggenhed som midtpunkt i familiens vidtstrakte besiddelser i den skønne egn nær Flensborg fjord gjort den overordentlig attrået.

Søgård lå på et næs, men var helt afskåret fra landsiden af stærke volde og grave. Af en bemærkelsesværdig, ganske primitiv skitse af anlægget fra 1569, som Jørgen Ahlefeldt-Laurvig har fremdraget, ${ }^{6}$ fremgår det, at adgangen til borgen fandt sted ad en lang bro, der førte over til søens nordlige bred, hvor avlsgården vistnok lå. At dømme efter nogle undersøgelser fra 1846, da landevejen blev anlagt, var selve borgholmen skærmet af en omgivende vold på 60 skridts bredde. Herefter fulgte voldgraven, der var ganske smal, 10-12 skridt bred, og endelig var der en bræmme land på ca. 20 skridt mellem graven og selve borgmurene. Man har tydeligt lagt vægt på at gøre anlægget svært tilgængeligt. Broen ramte ikke næsset midt for borgen, men ved dens nordøstlige hjørne, og passagen gennem volden var ligesom den næste bro over voldgraven til portfløjen lagt diagonalt. Angribere havde altså ingen muligheder for at beskyde borgporten på afstand.

Anlæggets stærkt befæstede karakter forklarer fuldt ud, at Søgård af de første Ahlefeldt'er på stedet blev stillet til rådighed for de holstenske grever $\mathrm{i}$ deres fejder mod Erik af Pommern. Søgård har simpelthen været en vigtig militær brik i spillet om Sønderjylland. Ved middelalderens slutning og i det 16 . århundrede har det været forbundet med en betydelig prestige og - $\mathrm{i}$ samtidens øjne - store praktiske fordele for en adelig familie at kunne disponere over en fæstning som bolig, hvor eventuelle opsætsige bønder eller fjendtligsindede standsfæller blev holdt på afstand. 
På skitsen fra 1569 er der på voldterrænet mellem søen og voldgraven anført flere stalde og økonomibygninger, men det kan være senere tilføjelser. I det øjeblik, Søgård blev bolig for flere familier med hver

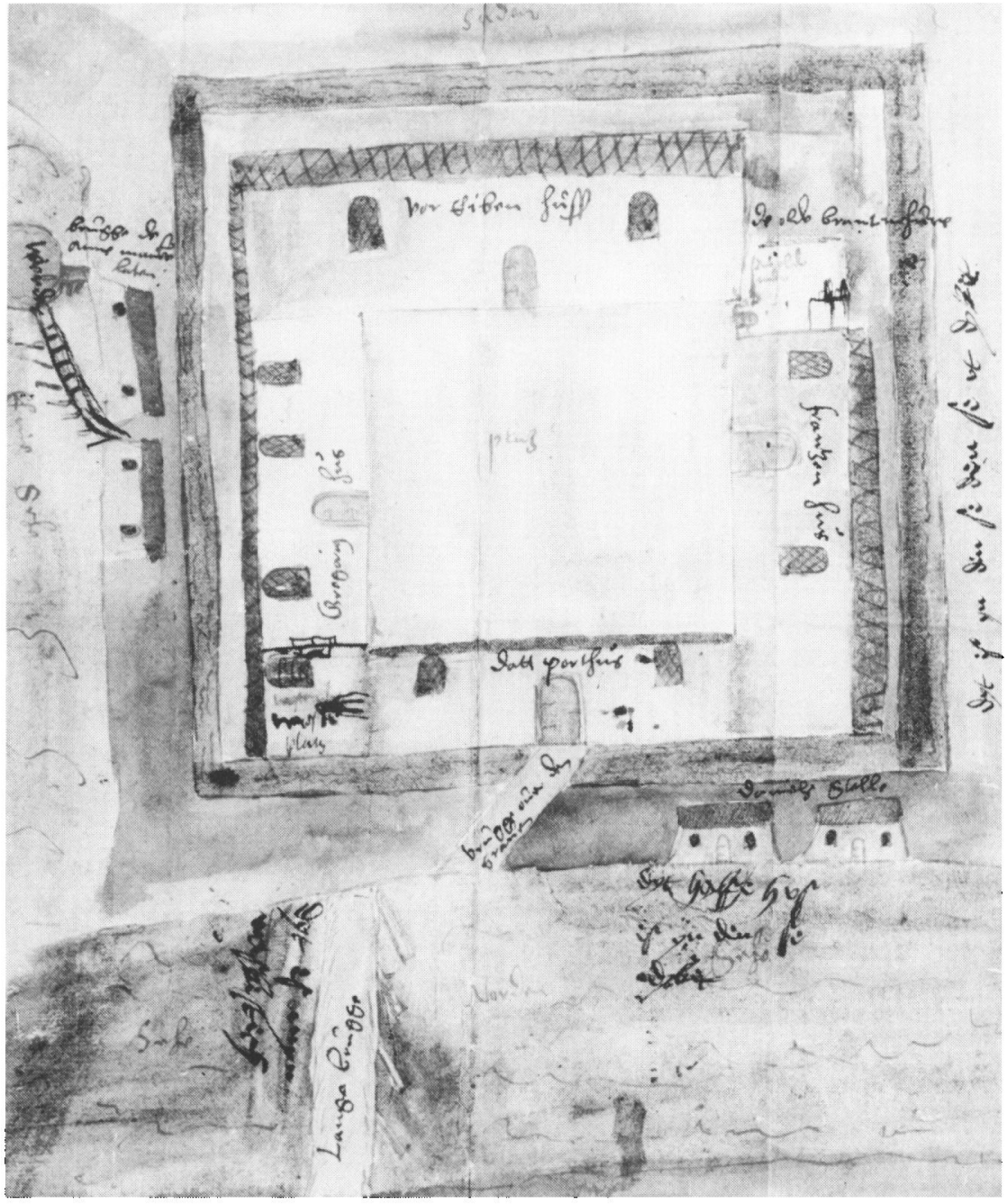

Plan over Sogård under familiestriden 1569. På den primitive, men egentlig ret anskuelige skitse er broer, stalde og bygninger blevet "lagt ned". Fugleperspektivet, som umiddelbart kunne synes mere hensigtsmassigt, har tegneren ikke kendt. Det bemarkes, at syd er opad. Hovedbygningens fire fløje er fra venstre Gregers Ahlefeldts ostfloj, moderen, fru Eibes sydfloj, Frantz Ahlefeldts vestfloj og den nordre portfløj.

Originalen findes på landsarkivet $i$ Slesvig. Det her benyttede foto er venligst udlänt af Jorgen Ahlefeldt-Laurvig, Eriksholm. 
deres husholdning, måtte pladsen i de forhåndenværende udhuse på selve borgholmen snart blive trang. Det gjaldt selvsagt især, hvis familierne ikke kunne enes, og det viste sig desværre hurtigt at være tilfældet. Kun dødsfald i de to Ditmarskerkrige 1500 og 1559 hindrede vist striden $i$ at bryde ud i lys lue. Skitsen fra 1569 stammer netop fra en retssag, som skulle forlige de stridende parter. Af skitsen ses, at Søgård på dette tidspunkt var et stateligt firfløjet anlæg, hvor dog kun vestog nordfløjen og øst- og sydfløjen var bygget helt sammen. I mellemrummene blev der plads til en vaskeplads, et brændehus og andre forrådsbygninger.

At disse fælles faciliteter kunne give anledning til strid, da Søgård snart splittedes $\mathrm{i}$ både to og tre husholdninger, er let at forestille sig. En ejendommelig detalje på 1569-skitsen røber, at det faktisk var tilfældet, hvad skitsen og retssagen jo i sig selv er vidnesbyrd om. Ved siden af den lange bro, der førte over til avlsgården på den nordlige søbred, er der hastigt skitseret endnu en bro med den indignerede påskrift: »Dette er min bro eller bræt«. Bemærkningen og det besynderlige arrangement kan vanskeligt opfattes anderledes end, at skitsens ophavsmand er blevet forment retten til at benytte den sædvanlige adgangsvej til Søgård og har måttet opføre sin egen interimistiske broforbindelse. På samme måde kan bygningerne på det ydre voldterræn være blevet til. Om flere stalde anføres, at de rager halvvejs ud i søen. Fra østsiden af anlægget udgår endnu en bro, der fører over til et næs, hvorfra man kunne komme videre til Søgårds marker. Var østfløjens indehaver forment adgang til hovedindgangen, rådede han altså til gengæld over denne bagvej.

I 1490'erne var fordrageligheden nok større. De problemer, der fandtes, fik en tragisk løsning, da Jørgen Ahlefeldt faldt i slaget ved Hemmingstedt 1500 . Herefter sad tilbage broderen Benedikt og efter hans død ca. 1510 hans enke, Eibe Rantzau, hvis moder, Margarethe Ahlefeldt, i øvrigt var en datter fra Tørning og søster til hr. Hans. Da Jørgen Ahlefeldt og hans hustru, Anna Meinstrup, i deres korte ægteskab ingen børn havde, mens fru Anna dog havde flere børn i sit tidligere agteskab med Holger Rosenkrantz til Boller, blev hun som enke bogstaveligt talt sat på porten. Det gav anledning til vidtløftige processer, som den trættekære fru Anna forgæves førte mod sin svigerinde. I disse år, hvor fru Eibe blot delte borgbygningerne med sin mestendels fraværende svoger, ærkedegnen, må husfreden for en stund have hersket på Søgård.

I 1490'erne havde de to brødre, Benedikt og Jørgen, delt vestfløjen, 
mens moderen antagelig boede i sydfløjen og ærkedegnen i østfløjen. Efter svigermoderens død må fru Eibe være rykket over i sydfløjen, der sikkert har været hovedhuset. I 1569 kaldes denne fløj fru Eibes hus. Hendes ældste søn, Frantz Ahlefeldt, har da overtaget vestfløjen, mens hans yngre broder Gregers senest ved ærkedegnens død 1540 er rykket ind i østfløjen. Gennem tiderne er der naturligvis foregået mange byggearbejder og forandringer, således at dette billede må gives med alle forbehold. I 1535, mens fru Eibe endnu levede, delte brødrene Søgård imellem sig, hvorved det ejendommelige begreb Halvsøgård opstod, som deres børn, børnebørn og oldebørn skrev sig til. Ved denne lejlighed fik Frantz portføjen, mens Gregers fik lovning på sydfløjen efter moderens død, som formodentlig har fundet sted ret kort efter.

Situationen ved århundredets midte var altså den, at Frantz sad på vest- og nordfløjen, der netop var bygget sammen på 1569-skitsen, ligesom øst- og sydfløjen, hvor Gregers residerede. Herved bliver det besynderlige broarrangement på 1569-skitsen forklarligt, idet portfløjen og dermed hovedindgangen tilhørte den ene broder og hans familie. Imidlertid var begge brødre efter årtiers rivninger døde. Frantz faldt $\mathrm{i}$ slaget ved Heide 1559, mens Gregers blev såret og døde få dage senere. Åbenbart har ingen af dem holdt sig tilbage, da det gjaldt. Deres respektive dele af Søgård gik videre til deres arvinger - og herved mødtes atter slægtens to hovedlinier, Søgård- og Tørning-linierne, der nedstammede fra Benedikt II til Grimstrups to sønner.

\section{Haseldorf-linien og Halvsøgård}

Tørning-linien var, som allerede skildret, blevet forrykket til det sydligste Holsten. På Haseldorf sad i det 16. århundredes første halvdel et overordentlig virksomt ægtepar, den faldne hr. Hans’ søn Frederik Ahlefeldt (1492-1541) og hans hustru, Catherine Pogwisch (ca. 1500-1561). Fra dette ægtepar nedstammer alle nulevende danske og tyske Ahlefeldt'er. Med stor energi og vist også en betydelig hensynsløshed forstod Frederik Ahlefeldt og senere hans enke at udvide og nyttiggøre familiens nye besiddelser. Store arealer blev inddiget og lagt under plov. Det gav anledning til mange stridigheder med bønderne, der mistede deres græsning og i stedet blev tvunget til at udføre digearbejderne som hoveri. Med naboen, territoriet Pinneberg, der tilhørte de yngre schauenburgske grever og blev styret af en drost, lå familien 
på Haseldorf også i stadig strid. Tilsammen havde Pinneberg og Haseldorf monopol på den indbringende færgefart over Elben, men Pinneberg beholdt indtægterne for sig selv, hvorved det indbyrdes forhold allerede blev spændt. Hertil kom stridigheder om skove, jagt og jorder, som begge parter gjorde krav på, stridigheder, der til tider førtes med stor voldsomhed. Ved en lejlighed lod drosten sine folk køre med vogne, hvis baghjul var taget af, i nogle omstridte marker, som fru Catherine og hendes sønner havde tilsået, hvorved kornet blev ødelagt. ${ }^{?}$ Ved en anden blev den unge Hans Ahlefeldt taget til fange under en stragejagt, idet drosten bestred Ahlefeldt'ernes ret til at udøve denne form for jagt. ${ }^{8}$

I denne fejdeagtige atmosfære voksede Hans Ahlefeldt (ca. 1525-1559) og hans brødre Benedikt og Wulf op. Hans var vistnok den aldste, idet han nævnes forst og utvivlsomt har været opkaldt efter farfaderen, hr. Hans. Haseldorf omfattede oprindeligt hele Elbmarsken fra Pinneberg indtil Krempe marsk ved Stör-floden, men Frederik Ahlefeldts brødre fik ved arvedelingen 1517 de nordlige godser Kollmar og Neuendorf, således at Haseldorf herefter grænsede til åen ved Elmshorn. Ved en ny arvedeling 1551, der efter tidens skik foregik ved lodtrækning, blev godset yderligere opdelt. Den ældste af Frederik Ahlefeldts sønner, Hans, fik Seestermühe, Wulf fik Haselau samt Kaden, og Benedikt - eller Bendix, idet man snart foretrak den nedertyske, protestantiske udgave af det gamle familienavn - fik selve det efterhånden stærkt formindskede Haseldorf. Under disse omstændigheder, der snart krydredes af nye, delvis korporlige stridigheder mellem brødrene indbyrdes, er det vel naturligt, at den unge, foretagsomme Hans Ahlefeldt så sig om efter andre muligheder og herunder havde opmærksomheden rettet mod sine fjerne frænder i Sønderjylland.

Vi forlod Frantz Ahlefeldt i vestfløjen på Søgård, hvor han også rådede over portfløjen med tilhørende bro. I 1535 omtales vestfløjen som »den gamle bygning«, mens østfløjen kaldes »stenhuset«, men på skitsen fra 1569 er vestfløjen tydeligt et nyt stenhus, som Frantz må have opført ved århundredets midte. Frantz Ahlefeldt og hans hustru, Catherine Pogwisch, havde kun døtre, idet deres eneste søn, der skulle have været endnu en af den lange række af Benedikt'er på Søgård, var død i en spæd alder. Den ene datter, Mette, forblev ugift og var utvivlsomt et århundrede tidligere gået $\mathrm{i}$ kloster. Hun blev affundet med et mindre gods, Årtoft vest for Søgård. Tilbage var som arving til Halvsøgård og et af hertugdømmernes bedste partier den anden datter, Dorothea (ca. 1540-1599). 
Den 29. september 1555 fejrede Frantz Ahlefeldt på Søgård denne datters bryllup med Hans Ahlefeldt til Seestermühe. Foruden den sædvanlige medgift fik brudgommen Halvsøgård i sin svigerfaders testamente. Det unge ægtepars lykke blev imidlertid kort. Knap fire år senere udåndede Hans Ahlefeldt på Seestermühe. Formodentlig er han blevet hårdt såret i slaget ved Heide en måned tidligere, hvor også svigerfaderen faldt.

Tilbage sad Dorothea med to spæde børn, en søn og en datter, og et tredie på vej. I 1566 blev hun gift med Daniel Rantzau til Hohenfelde mellem Elmshorn og Itzehoe, og det var denne mand - ikke at forveksle med Syvårskrigens feltherre - som senere på sin hustrus vegne førte den standende familiestrid om Søgård. Daniel Rantzau var endvidere årsag til, at Søgård ved lidt af en tilsnigelse blev optaget $i$ det store værk om Rantzauernes borge, som Heinrich Rantzau foranstaltede udgivet i 1590 . Her er Søgård fremstillet med en stor spærremur tværs over gårdspladsen, som karakteristisk nok overlader porten til Frantz' del. ${ }^{9} \mathrm{Da}$ muren ikke kendes fra andre kilder, er der dog snarest tale om en fri illustration af det velkendte forhold, at Søgård var delt $i$ to halvdele.

\section{Søgård samles}

Efter Ditmarskerkrigen har der været sorg i begge dele af Søgård. På den anden side af gårdspladsen sad Gregers' enke Anna Ahlefeldt med seks børn, Dorotheas fætre og kusiner. Anna Ahlefeldt var datter af Godske Ahlefeldt til Saxtorf og således en slags kvartkusine til sin mand. Hos sig havde hun endvidere sin broder Philip, der året før var vendt hjem fra udenlandsk krigstjeneste. Philip Ahlefeldt blev boende i de følgende år og styrede Halvsøgård - Gregers' halvdel - for søsteren og hendes umyndige børn, indtil han i $1580 \mathrm{blev}$ dræbt af Oswald von der Wisch til Ascheberg. Måske er det ham, der har udfærdiget skitsen fra 1569 , hvor han påberåber sig sit »bræt«, den interimistiske broforbindelse, der var anlagt $\mathrm{i}$ konkurrence med den officielle bro.

I mellemtiden havde Gregers' søn Hans Ahlefeldt (ca. 1540-1580) overtaget faderens Halvsøgård. Han og hans hustru, Margarethe Rantzau, tog sig straks for at gennemføre en tiltrængt istandsættelse af fru Eibes gamle hus, Søgårds sydfløj. Af arkæologiske fund af gulvfliser og tagsten, Jørgen Ahlefeldt-Laurvig har fremdraget, ${ }^{10}$ fremgår, at der blev indrettet en række prægtige rum, og at bygningen udefra må have 


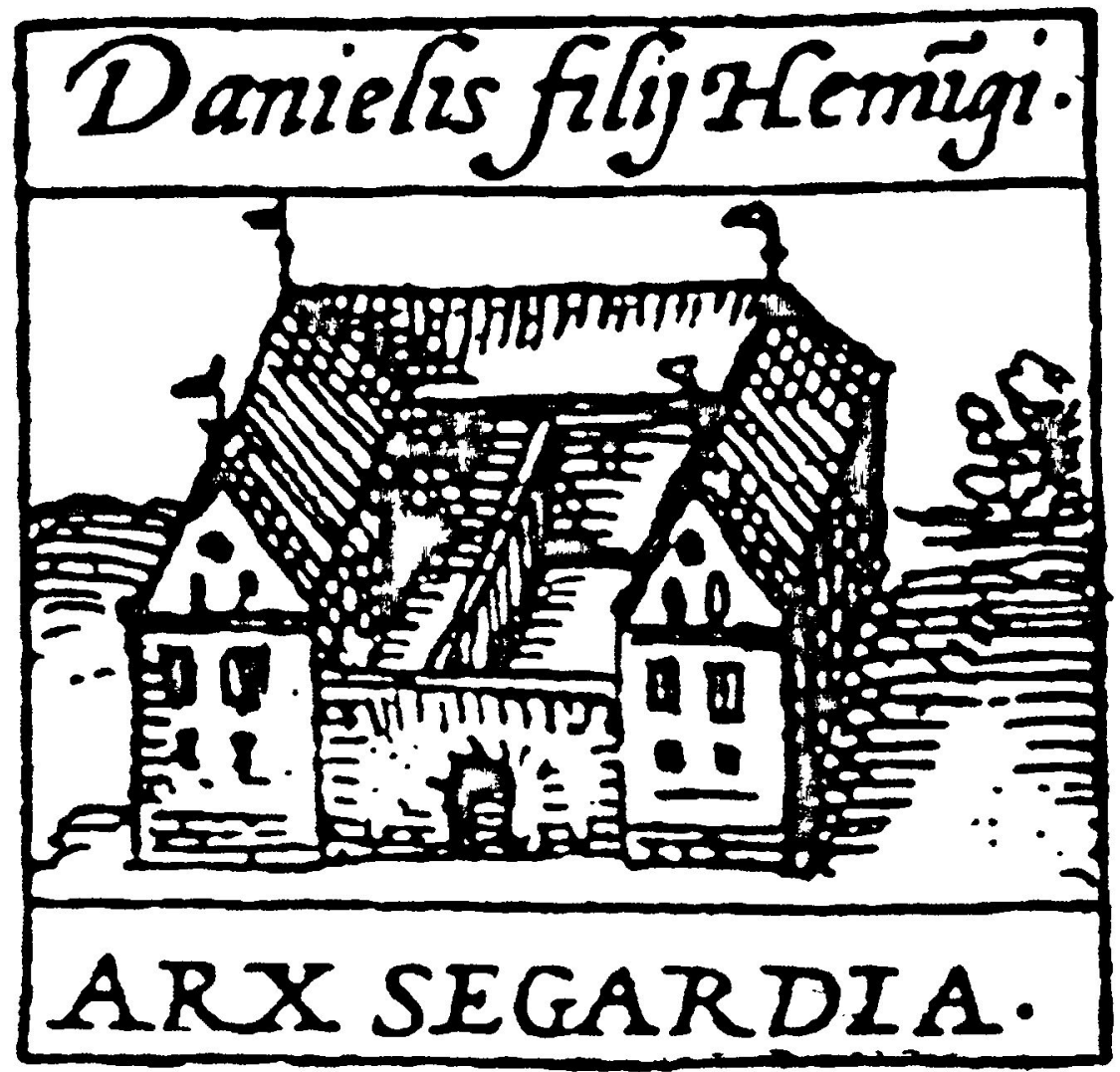

Søgård på den rantzauske slagtstavle (kobberstik i Henninges: Genealogia 1590). Overfladisk set stemmer anlagget med kortskitsen, men om lighed $i$ vor forstand er der nappe tale. Tegningen symboliserer blot, at der var tale om et anseligt bygningsvark. Interessant er muren, der - korrekt - henforer borgens port til vestflojen. Om gårdspladsen virkelig har varet delt, eller om muren skal forstås $i$ overfort forstand som en hentydning til begrebet Halvsøgård, vides ikke. Daniel Rantzau, Hemmings son, der er anfort som ejer, var gift med Frantz Ahlefeldts datter og kom på denne måde $i$ besiddelse af vest- og portflojen af Sogård. Det er til ham påskriften "Daniels stalde" på kortskitsen fra 1569 sigter. Påskriften skimtes mellem volden og de to staldbygninger, der rager ud $i$ søen vest for portåbningen.

stået som et broget og farvestrålende skue. Til disse byggearbejder sigter formodentlig en højst usædvanlig gengivelse af et stateligt bygningsværk med tårne og spir og en portbygning med kamtakket gavl, der findes på Hans Ahlefeldts gravsten i Kliplev kirke. 


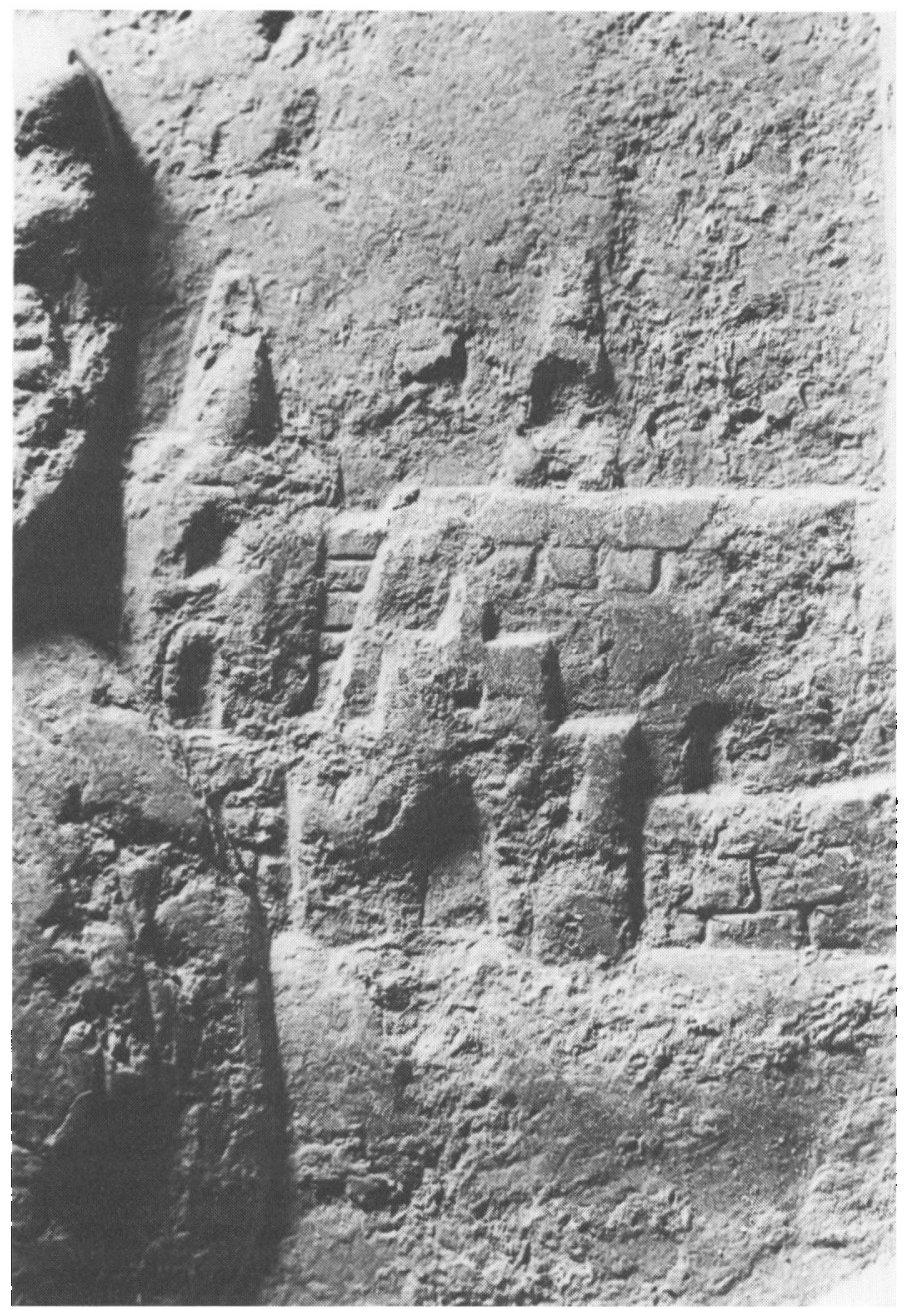

På Hans Ahlefeldts (+1580) og Margrethe Rantzaus gravsten i Kliplev kirke ses hojst usadvanligt et bygningsvark, der muligvis sigter til deres byggearbejder på Sogård. Hele Ahlefeldt'ernes stolte borg blev imidlertid odelagt under Torstenssonfejden 1643-44. Museet på Sonderborg slot.

Herefter synes det, som om man blev træt af stedet og de evige kævlerier, der var forbundet med to familiers ophold i samme bygningskompleks. Allerede den ældre Gregers havde anlagt et jagthus på halvøen Troldsløkke, hvor nu Gråsten by ligger, og som efterhånden 
udviklede sig til en avlsgård. Da bygningerne brændte 1603, flyttede Hans Ahlefeldts unge søn, Gregers (ca. 1577-1617), Gråsten avlsgård over på den anden side af noret, hvor han byggede sig en smuk residens, kærnen i det nuværende kongelige slot.

Også den anden familie på Søgård foretrak efterhånden andre boliger. Hans og Dorothea Ahlefeldts eneste søn, Frederik Ahlefeldt (ca. 1557-1605), opholdt sig tilsyneladende mest på Årtoft, som hans moster Mette må have givet fra sig. Det kan naturligvis skyldes, at moderen, fru Dorothea, stadig rådede over Søgårds vestfløj - og portfløjen har næppe været noget tiltalende alternativ. På Årtoft døde Frederik Ahlefeldts unge hustru, Catherine, der var en datter af Heinrich Rantzau på Breitenburg, allerede i 1587. Herefter begav han sig på en større udenlandsrejse, og i 1597 blev han amtmand i Aabenraa, hvor han havde sin embedsbolig på Brundlund slot."

I alle disse år har Frederik Ahlefeldt kun i meget begrænset omfang kunnet opholde sig på Søgård, og ved hans tidlige død splittedes hans godser mellem hans mange børn. Halvsøgård arvedes af hans eneste overlevende søn, der også hed Frederik Ahlefeldt (1594-1657). I hans tid fandt der - helt bogstaveligt - en tilnærmelse sted mellem de to Søgård-linier. I 1619, vistnok efter Gregers Ahlefeldts død, blev Frederik Ahlefeldt gift med hans datter og sin egen »kvartkusine«, Birgitte, der synes at have været den ældste af hans og Mette Blomes store børneflok. Har det spillet en rolle, at Frederik Ahlefeldts fader i sit andet ægteskab også var gift med en Blome? Da begge fædre var døde, var det altså en moder og en stedmoder af slægten Blome, der bortgiftede deres respektive børn.

Det unge ægtepar bosatte sig på Søgård, hvor Birgitte Ahlefeldt i de følgende år fødte en række børn, og parret stod tilsyneladende i det bedste forhold til svogeren, Hans Ahlefeldt (ca. 1605-1663), ejer af den anden Halvsøgård. Imidlertid væltede ulykkerne ind over Danmark. Allerede under Kejserkrigen 1627 måtte familien flygte til Sjælland. Søgård lå udsat tæat ved den gamle hærvej, og over for 1600-tallets artilleri var de gamle fæstningsværker intet værd. Selv det uindtagelige Breitenburg blev ved denne lejlighed stormet og plyndret af Wallensteins tropper. Da den svenske feltmarskal Torstensson 1644 rykkede op i Jylland, blev Søgård ramt af samme skæbne.

Da var Birgitte Ahlefeldt allerede død, og under de ulykkelige forhold kunne familien let have gået sin undergang i møde, hvis ikke endnu et heldigt giftermål atter havde bragt denne gren af den ahlefeldtske slægt storhed og glans. Også dette ægtepar havde kun haft en 
enkelt overlevende søn, den tredie Frederik på rad. Denne Frederik Ahlefeldt (1623-1686) skulle blive slægtens mest fremtrædende medlem, rigsgreve, dansk lensgreve og storkansler. Efter et stormfuldt ungdomsliv blev han i 1654 vistnok ved lidt af et tilfælde nært knyttet til hoffet. Under pesten i København havde kongeparret taget ophold på Flensborghus, hvor den forlystelsessyge dronning Sophie Amalie fordrev tiden med en række glimrende fester. Til disse fester blev egnens landadel indforskrevet, og Frederik Ahlefeldt, der åbenbart hørte til de "bastante" mænd, som dronningen foretrak, blev hurtigt en af hendes erklærede yndlinge.

Derimod brød hun sig absolut ikke om hertugdømmernes daværende førstemand, den hovedrige statholder Christian Rantzau til Breitenburg. Lunefuld og intrigant, som hun var, har det utvivlsomt moret dronningen at spille den fornemme statholder et puds. Under højst uklare omstændigheder, men tydeligt skærmet af en hofintrige bortførte Frederik Ahlefeldt i 1656 statholderens kun 14-årige datter, Margarethe Rantzau, og blev den 26. december i nærheden af Lübeck viet til hende.

Dette ægteskab, som Christian Rantzau først to år senere yderst modstræbende og under pres fra kongehuset gav sit samtykke til, gjorde Frederik Ahlefeldt til en af monarkiets mest formuende mænd. Foruden en kontant medgift på 25.000 rigsdaler kom han i besiddelse af hele Tranekær amt, som Christian Rantzau havde fået overladt af kronen for sine udlæg under Torstensson-krigen. Ved svigerfaderens død få år senere arvede han atter en kolossal sum penge. Samtidig steg han hastigt i graderne. Under de stærkt forandrede forhold, som Svenskekrigene og statsomvæltningen 1660 gav anledning til, blev han en af de ledende statsmænd. Han førte stort hus i København og på Gråsten, hvor han byggede og udvidede morfaderens enkle residens til et stateligt slot, fyldt med kostbare samlinger og omgivet af en yndefuld park. Efter sin svigerfader blev han statholder i hertugdømmerne og faktisk leder af monarkiets udenrigspolitik. Det var en selvfølge, at han i 1672 blev ophøjet i den nyoprettede danske grevestand, idet Langeland forvandledes til et arveligt grevskab for ham og hans slægt, og i 1676 - efter Griffenfelds fald - fulgte udnævnelsen til storkansler og præsident i statsrådet.

Fra at være en sønderjysk landjunker i beskedne omstændigheder var Frederik Ahlefeldt blevet rigets mægtigste mand efter kongen. Det er forståeligt, at han midt $\mathrm{i}$ al denne storhed ikke fandt tid til at tage sig af fædrenegården, Søgård, der nu lå hen som ruin. Også her havde 


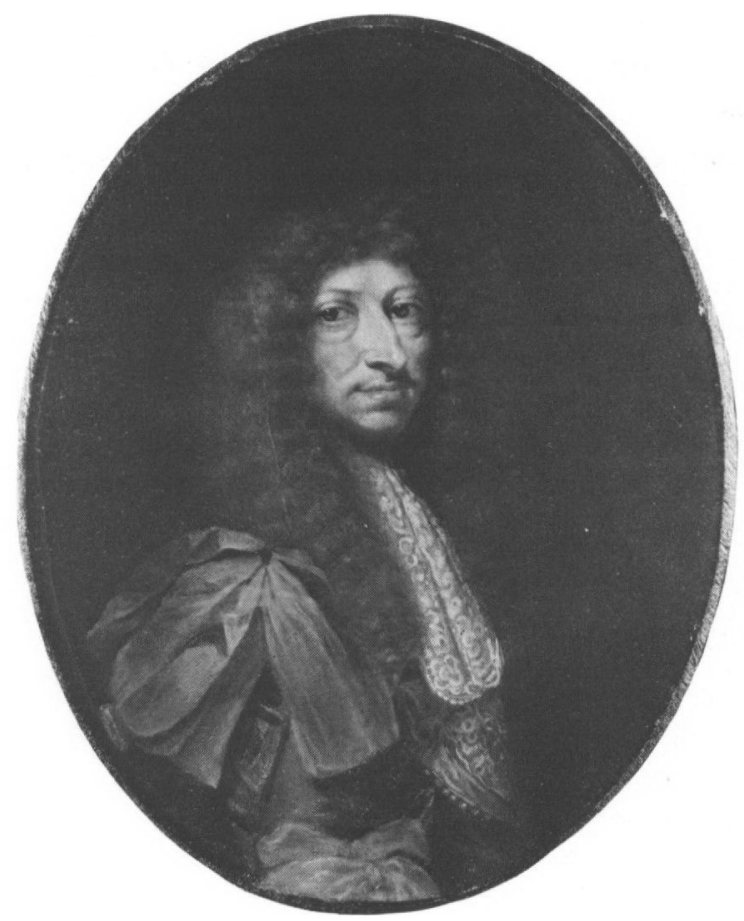

I Frederik Ahlefeldts (1623-86) barndom var Søgård narmest en ruin, efter fjendernes hargen. Men Frederik drev det vidt. Han blev eneejer af Søgård, ejer af Gråsten, greve af Langeland, statholder $i$ hertugdommerne, leder af Danmarks udenrigspolitik, og meget mere. Storkansleren, en af Danmarks magtigste mand, er her malet af Abraham Wuchters. Lennart Larsen foto. Frederiksborg. Kopi i Historiske Samlinger for Sonderjylland.

lykken ellers stået ham bi. Efter faderens og morbroderens død var begge Halvsøgårde tilfaldet ham, og for første gang, siden Benedikt Ahlefeldt levede på Erik af Pommerns tid, var hele det gamle Søgård gods samlet på én hånd.

Efter Torstensson-krigens ødelæggelser synes avlsgården at være blevet flyttet vest for søen, hvor Søgård kaserne nu ligger. Bygningerne på selve borgholmen er der næppe blevet gjort noget forsøg på at genopbygge, men antagelig er der blevet indrettet en beboelse til familien $\mathrm{i}$ forbindelse med avlsgården. Her må Frederik Ahlefeldt have holdt til, mens han optrådte som selskabsløve på Flensborghus. Efter at han i 1661 havde fejret sin første store diplomatiske triumf ved at afslutte Whitehall-traktaten i London, oplyses uformidlet, at »folkene 
fra Søgård« hentede hans bagage, da han på vejen til København passerede Flensborg. ${ }^{12}$ Her havde han altså endnu sit hjem.

Også Søgårds sidste ejer af slægten, lensgreve Carl Ahlefeldt (1670-1722), boede her, når han gik på jagt. En fuldstændig overdådig livsførelse kombineret med tidernes ugunst bevirkede, at Søgård og alle slægtens sønderjyske besiddelser gik tabt. For slægten var det et held, at grevskabet Langeland i tide var sikret mod insolvens, og Tranekær blev i de følgende århundreder Ahlefeldt'ernes danske hovedsæde.

\section{HENVISNINGER OG NOTER}

1. Louis Bobé: Slægten Ahlefeldts Historie II, noter s. 78.

2. L. Bobé, bilag s. 3-6.

3. Jf. stamtavlen i Danmarks Adels Aarbog 1985.

4. L. Bobé I s. VI.

5. L. Bobé II, bilag s. 9-13, jf. Jørgen Ahlefeldt-Laurvig i Egernførde Bys Historie s. 95-98.

6. Nordslesvigske Museer 1980 s. 47-54.

7. E. Andersen: De hansborgske Registranter II s. 498-500. Hos Bobé, IV s. 75 , er det blevet til en historie om, at drostens folk om natten høstede kornet og førte det til Pinneberg.

8. O. Kalkar: Ordbog til det ældre danske Sprog IV s. 156-57 oplyser: Mulig jagt af omvandrende jæger, modsat klapjagt o.lign.?

9. V. Lorenzen: Rantzauske Borge s. 58.

10. Nordslesvigske Museer 1980.

11. Jf. H.V. Gregersen i Sønderjyske Årbøger 1955 og i Sønderjysk Månedsskrift 1965.

12. L. Bobé VI, henvisninger s. 56. 